\title{
PELATIHAN INTERNET SEHAT SEBAGAI ANTISIPASI CYBER BULLYING ANAK REMAJA DI PANTI ASUHAN "KEMALA PUJI" BANDAR LAMPUNG
}

\author{
${ }^{1}$ Kurnia Fadila, ${ }^{2}$ Hary Sabita, ${ }^{3}$ Anandha Sartika Putri, ${ }^{4}$ Joko Triloka \\ 1,3Manajemen Fakultas Ekonomi dan Bisnis Institut Informatika dan Bisnis Darmajaya \\ ${ }^{2,4}$ Teknik Informatika Fakultas IImu Komputer Institut Informatika dan Bisnis Darmajaya \\ e-mail: kurniafadila@darmajaya.ac.id
}

(Diterima: 13 Oktober 2021; Direvisi: 30 Oktober 2021; Dipublikasikan: November 2021)

\begin{abstract}
Abstrak
Latar belakang anak asuh yang ada di lembaga sosial panti asuhan Kemala puji kebanyakan dari keluarga yang kurang mampu yaitu anak-anak yatim piatu, terlantar, dan anak jalanan. Lembaga melayani, mengasuh, serta memberdayakan dengan memberikan penghidupan yang layak. Kepekaan masyarakat terhadap pemberdayaan anak yatim piatu yang dibina langsung oleh lembaga perlu adanya peningkatan yang lebih baik. Hal ini karena anak-anak tersebut pantas di jadikan generasi penerus bangsa. Pengabdian masyarakat ini bertujuan untuk menumbuhkan rasa kepedulian sosial antar sesama manusia pada remaja, khususnya bagi anak-anak yatim di panti asuhan tersebut dengan melakukan sosialisasi dan pembelajaran tentang internet sehat yang bertujuan meningkatkan pemahaman anak-anak panti bagaimana cara menggunakan internet dengan baik dan sehat serta sebagai antisipasi tindakan cyber bullying terhadap anak-anak. Metode pelaksanaan dalam kegiatan ini yaitu dengan metode penyuluhan, diskusi, simulasi, dan penerapan dengan tahapan kegiatan yaitu tahap pra-pelaksanaan, tahap pelaksanaan dan tahap dokumentasi. Hasil dari kegiatan pelatihan adalah anak-anak remaja panti memiliki pemahaman penggunaan internet sehat, serta memiliki keterampilan yang cukup dalam menggunakan internet dengan baik dan benar yang diberikan pada saat pelatihan.
\end{abstract}

Kata Kunci: internet sehat, cyber bullying, panti asuhan

\section{Abstract:}

The background of foster children in Kemala Puji orphanage are mostly from poor families, orphans, neglected, and homeless child. The institution have been serve, nurture, and empower by providing them a sufficient living. Hence, it still needs a better improvement. This is because these children deserve to be made for the next generation. This activity aims to rise of social care between humanity in adolescents, especially for children in the orphanage. This have been done by imparting knowledge to them about healthy internet. Moreover, its increases understanding how to use the internet more healthily, properly and to anticipate of cyber bullying against them. The outcome of training activities are the youth children have been understood how to use a healthy internet, and they have been sufficient skills how to use internet which was given during the training.

Keywords: healthy internet, cyber bullying, orphanage 


\section{PENDAHULUAN}

Panti Asuhan Kemala Puji bertempat di Jl. Pramuka, Langkapura, Kota Bandar Lampung, Provinsi Lampung. Panti Asuhan Kemala Puji Bandar Lampung memiliki keseluruhan anak asuh berjumlah 25 dengan perincian: 8 anak usia sekolah dasar (SD), 15 anak usia sekolah menengah pertama (SMP) dan 2 anak usia sekolah menengah atas (SMA). Merujuk pada data tersebut, terdapat 17 anak pada jenjang pendidikan menengah yang rentan terhadap penggunaan Internet.

Peluang untuk mendapatkan informasi, baik konten positif maupun negatif, semakin terbuka. Pengaruh konten negatif sudah sering diberitakan di berbagai media berupa pemuatan gambar porno, perjudian, penipuan, pelecehan, pencemaran nama baik dan berita bohong (Susanto, 2015). Selain itu penggunaan jejaring sosial juga memiliki dampak negatif, salah satunya adalah cyber bullying yang biasanya menimpa anak-anak dan sesama remaja. Untuk menghindari kejahatan di dunia maya, selalu ditekankan prinsip dasar penggunaan internet yang harus diketahui oleh pengguna (Purnamasari, 2017) (Surdin, 2016). Penggunaan internet secara sehat dan aman perlu ditanamkan semenjak dini melalui pembelajaran etika berinternet secara sehat (RI, 2008).

Internet dan akses terhadapnya merupakan kebutuhan kontemporer bagi setiap orang yang mengharapkan kepraktisan dan kemudahan, tidak saja terbatas pada kalangan pengusaha tetapi juga para pendidik dan peserta didik di sekolah (Nurul Iman., 2014). Akses terhadap internet bagi anak-anak sekolah bukanlah sesuatu yang luar biasa karena pada umumnya sekolah-sekolah menengah pertama dan atas atau madrasah aliyah telah menjadikan internet sebagai sarana pembelajaran dan rujukan tugas di sekolah. Melalui warung internet (warnet), laptop, komputer di sekolah atau bahkan handphone, para siswa telah dapat mengakses. Kenyataan ini berbeda dengan keadaan para remaja penghuni panti asuhan yang dikarenakan berbagai keterbatasan mereka, internet masih menjadi barang yang mahal (Sujatmoko, 2010).

Program pembelajaran dan pelatihan intenet sehat bagi remaja panti asuhan Kemala Puji di Bandar Lampung dilaksanakan dengan pertimbangan utama, bahwa di panti asuhan ini, diduga masih banyak remaja panti asuhan yang belum menguasai internet. Sebagian yang menguasai baru tingkat dasar namun belum mampu menggunakan untuk berbagai keperluan untuk meningkatkan kompetensi diri, juga belum memahami dampak positif dan dampak negatif dari internet.

Oleh karena itu, kegiatan pelatihan ini difokuskan pada penggunaan aplikasi sosial media untuk berinternet secara sehat bagi remaja Panti Asuhan Kemala Puji. Melakukan pemberdayaan seperti pengabdian kepada masyarakat dalam bentuk pemberdayaan internet sehat bagi remaja Panti Asuhan Kemala Puji akan melahirkan kebermaknaan dan kebermanfaatan yang cukup tinggi bagi pembangunan manusia Indonesia. Para remaja tersebut dibina berkaitan dengan penggunaan internet. Selain itu, mereka dibekali dengan sejumlah ilmu tentang penggunaan internet sehat secara content/materi (agar terhindar dari plagiasi, pornografi/pornoaksi, penipuan dan sebagainya) dan juga berupa sikap seperti berapa waktu penggunaan internet yang sehat dan ideal dalam penggunaan internet, berapa jarak antara mata dan layar, bagaimana posisi duduk di depan layar dan sebagainya, sehingga internet sebagai sumber bahan belajar dan media yang dapat digunakan dalam menunjang kehidupan di era modern ini mampu dimanfaatkan oleh para remaja panti dengan maksimal. 


\section{METODE}

Metode pelaksanaan dalam kegiatan ini yaitu dengan metode sosialisasi/ penyuluhan, diskusi, simulasi, dan penerapan. Metode yang dilakukan dapat meningkatkan pengetahuan remaja panti tentang penggunaan internet secara baik dan sehat dengan tahapan kegiatan yaitu Tahap Pra-pelaksanaan, Tahap Pelaksanaan dan Tahap Dokumentasi.

\section{Tahapan Pra-pelaksanaan}

Pada tahapan pra-pelaksanaan kegiatan yang dilakukan adalah dengan menjalin kemitraan dengan pihak Pengelola panti asuhan Kemala Puji sebagai lokasi pelaksanaan program Pengabdian Kepada Masyarakat dengan diskusi mengenai solusi yang ditawarkan tim pengabdian, persetujuan pelaksanaan kegiatan, dan survey awal lokasi pelaksanaan program

\section{Tahapan Pelaksanaan}

Pada tahap pelaksanaan kegiatan yang dilakukan yaitu pertama, pelatihan mengenai internet sehat dan cyber bullying serta praktik berselancar di internet dengan benar. Yang kedua, berupa pemaparan materi mengenai motivasi berperilaku yang baik dan motivasi untuk menggunakan Internet dengan baik dan benar.

\section{Tahap Dokumentasi}

Tahap dokumentasi kegiatan pengabdian masyarakat ini yaitu dengan melakukan pengambilan gambar pelaksanaan program pengabdian masyarakat. Hasil dari dokumentasi tersebut digunakan sebagai bahan penyusunan laporan akhir dan pembuatan berita pengabdian masyarakat pada media massa online.

\section{HASIL DAN PEMBAHASAN}

Pelatihan dilaksanakan pada kalangan remaja Panti Asuhan Kemala Puji Bandar Lampung. Pelatihan dilaksanakan pada hari Sabtu, Tanggal 03 Juli 2021, dimulai dari pukul 09.00 hingga pukul 12.30 WIB yang dihadiri oleh 25 remaja penghuni panti beserta pengurus dan Pembina panti.

Sesuai dengan target utama bahwa pada pengabdian masyarakat ini, para remaja penghuni panti mengetahui cara penggunaan internet dengan sehat, baik dan benar. Maka, pada pengabdian masyarakat ini materi yang digunakan membahas seputar internet sehat dan bagaimana cara menggunakannya. Penyampaian materi pengabdian masyarakat terbagi menjadi 2 sesi yaitu: sesi 1 tentang internet sehat, sesi 2 tentang motivasi penggunaan internet sehat.

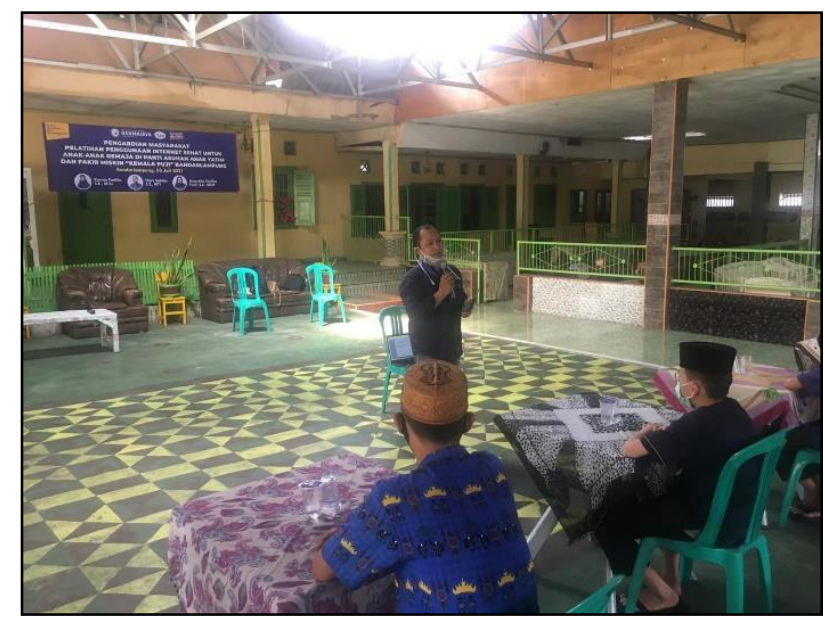

Gambar 1. Pemaparan Materi Pemateri Pertama. 
Pada gambar 1, pemateri pertama dari tim pengabdian masyarakat membahas tentang bagaimana konsep Internet secara umum, materi berinternet sehat yang dilakukan dengan cara yaitu: 1) Tidak berlama-lama didepan komputer; 2) Tetapkan tujuan berinternet; 3) Menggunakan internet untuk hal yang positif seperti menulis di blog; 4) Meng-upload konten video yang baik; 5) Berpikir terlebih dahulu sebelum memposting sesuatu di media sosial; dan 6) Bergabung dengan komunitas online yang mempunyai tujuan yang baik dan jelas, kemudian pemaparan cara penggunaan internet dengan baik dan benar serta cara menghindarkan anakanak dari dampak negatif dan bahaya internet yang dilakukan dengan cara: 1) Menghindari konten-konten yang berbau pornografi, dan sejenisnya; 2) Memberikan contoh yang baik bagi anak dalam menggunakan internet; 3) Membatasi waktu penggunaan internet; 4) mengaktifkan fitur safe search yang otomatis akan menyaring situs-situs yang berbahaya bagi anak; dan 5) Memeriksa secara berkala file yang telah diunduh dan dibuka oleh browser internet pada gadget anak. Setiap peserta mendengarkan secara seksama materi pelatihan yang diberikan oleh pembicara dan dibantu oleh panitia.

Lalu tahap kedua adalah tahap pemberian materi motivasi menggunakan internet sehat oleh Pemateri kedua. Pemateri memberikan berbagai informasi untuk menumbuhkan kesadaran para remaja akan situasi yang dapat terjadi apabila tidak berhati-hati saat menggunakan internet. Pemaparan dilengkapi dengan paparan materi mengenai kesadaran penggunaan internet sehat dan aman beserta cara penerapan yang menjadi solusi atas permasalahan dan situasi yang tidak diinginkan sehingga akan menciptakan kalangan remaja yang memiliki pemahaman akan penggunaan internet dengan aman, sehat, cermat dan bijak sehingga dapat meminimalisir dampak negatif dan memaksimalkan dampak positif dari internet.

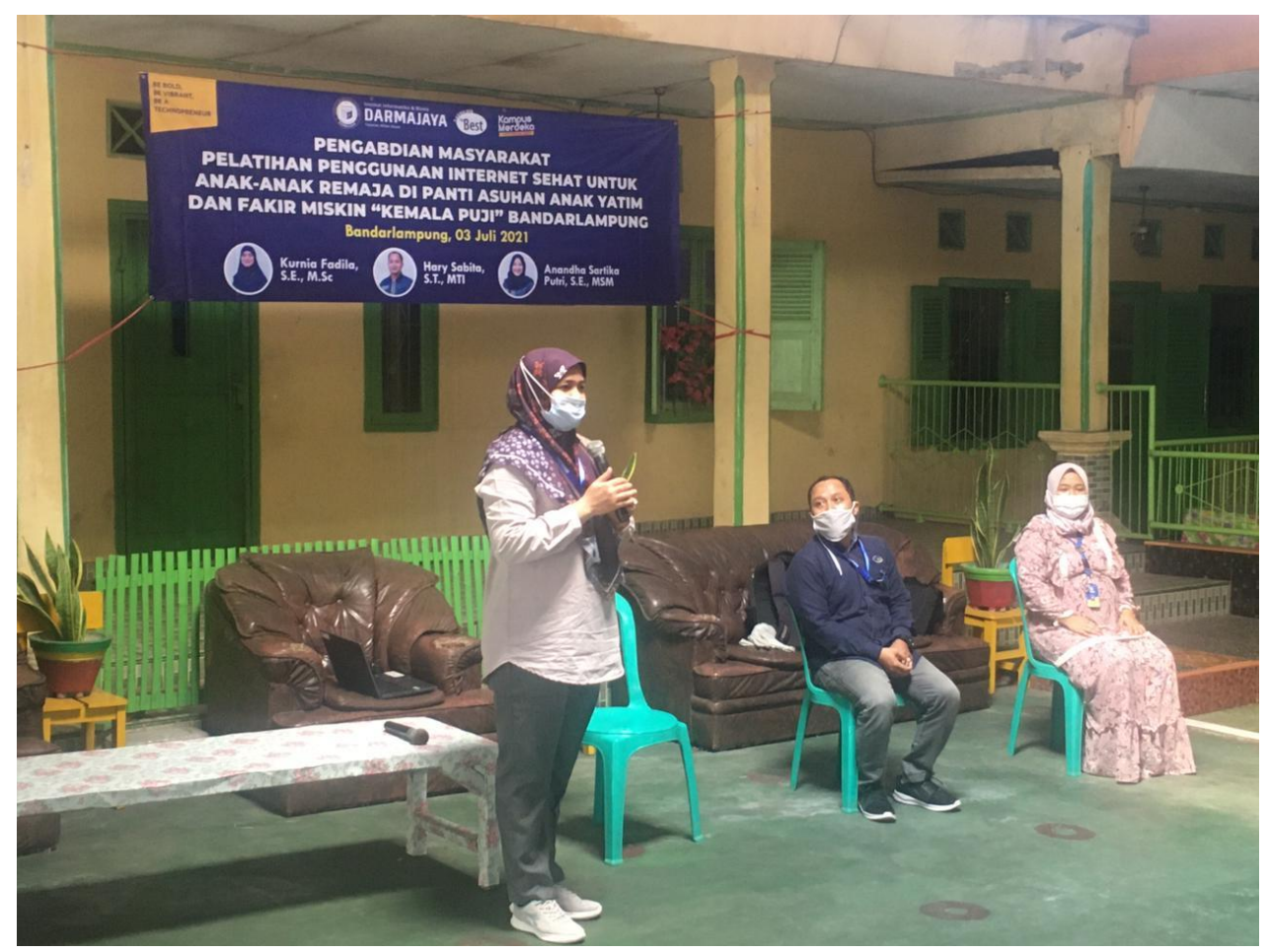

Gambar 2. Pemaparan Materi Pemateri Kedua. 
Pada sesi terakhir yaitu sesi tanya jawab, peserta mengajukan beberapa pertanyaan terkait pengunaan internet sehat atau saat menggunakan internet. Berikut beberapa pertanyaan yang dibahas pada sesi tanya jawab yang ditunjukkan pada Tabel 1.

Tabel 1. Daftar Pertanyaan Peserta

\begin{tabular}{|c|l|}
\hline No & \multicolumn{1}{|c|}{ Pertanyaan } \\
\hline 1 & Jika bermain game online termasuk penggunaan internet yang sehat atau tidak? \\
\hline 2 & Jika menonton drama korea merupakan penggunaan internet sehat atau bukan? \\
\hline 3 & Jika masih anak-anak boleh tidak membuat akun media sosial? \\
\hline 4 & Apakah boleh anak-anak menggunakan facebook? \\
\hline
\end{tabular}

Berdasarkan pertanyaan yang diajukan oleh peserta pada Tabel 1, secara garis besar, pertanyaan yang diajukan oleh peserta adalah seputar penggunaan entertainment menggunakan internet. Sehingga dapat diambil kesimpulan bahwa peserta belum dapat membedakan apakah hiburan merupakan hal dilarang atau diperbolehkan dalam penggunaan di internet. Adanya pelatihan ini dapat memberikan pemahaman kepada peserta akan hal yang diperbolehkan dan tidak diperbolehkan pada saat menggunakan intenet, sehingga dapat menggunakan internet secara bijak. Adanya pemahaman dan penerapan akan materi yang telah diterima akan membantu mereka terhindar dari resiko, bahaya, konten, situs, dan hal-hal lainnya yang bersifat negatif yang seharusnya tidak boleh dibaca dan diketahui terutama oleh kalangan remaja.

Pada pelatihan ini, para peserta kooperatif mengikuti pelatihan dan antusias mendengarkan pemaparan materi. Hal ini dibuktikan dengan adanya respon penghuni panti dalam menjawab pertanyaan yang diajukan pada sesi tanya jawab. Dengan adanya antusias dalam memberikan jawaban pertanyaan yang diajukan menunjukkan bahwa informasi yang disampaikan pemateri berhasil diterima dengan baik oleh peserta, sehingga permasalahan mengenai pemahaman konsep dan cara berinternet sehat dan aman remaja penghuni panti Kemala Puji yang masih rendah berhasil diselesaikan. Partisipan juga memberikan kesan, pesan, serta secara lisan terhadap pelaksanaan kegiatan.

\section{SIMPULAN}

Kegiatan pelatihan internet sehat yang dilaksanakan oleh tim pengabdian kepada kalangan masyarakat tepatnya kalangan remaja penghuni panti Kemala Puji berjalan dengan lancar. Materi akan pentingnya berinternet sehat dan aman berhasil disampaikan oleh tim pengabdian dengan jelas dan diterima dengan baik oleh tiap peserta. Kegiatan pelatihan ini mengedukasi para peserta akan pentingnya berinternet sehat dan aman serta dapat menggunakan internet secara bijak. Adanya pemahaman dan penerapan akan materi yang telah diterima akan membantu mereka terhindar dari resiko, bahaya, konten, situs, dan hal-hal lainnya yang bersifat negatif yang seharusnya tidak boleh dibaca dan diketahui terutama oleh kalangan remaja. Melalui pelaksanaan pelatihan ini menyelesaikan masalah akan rendahnya pemahaman konsep dan cara penggunaan internet sehat dan aman serta menghasilkan kalangan remaja penghuni panti yang dapat meminimalisir dampak negatif dan 
memaksimalkan dampak positif dari internet sehingga terciptanya kalangan masyarakat yang cerdas dan produktif kedepannya.

Adapun saran dan rekomendasi untuk perkembangan dan keberlanjutan kegiatan pelatihan ini kedepannya adalah menggunakan teknik pengumpulan dan analisis data dengan cara memberikan kuisioner ringkas kepada peserta mengenai kegiatan yang telah diikuti sehinggan pembahasan akan lebih terperinci.

\section{REFERENSI}

Nurul Iman., K. E. (2014). Internet Sehat Bagi Santri. Muaddib: Islamic Education Journal, 4(2).

Purnamasari, D. (2017). Undang Undang Republik Indonesia Nomor 6 Tahun 2014 Tentang Desa. Sinar Grafika.

RI, U. (2008). Undang-undang Republik Indonesia Nomor 11 Tahun 2008 Republik Indonesia tentang Informasi dan Transaksi Elektronik.

Sujatmoko, E. (2010). Hak Warga Negara Dalam Memperoleh Pendidikan. Jurnal Konstitusi, 7(1), 181-212.

Surdin, J. (2016). Analisis Kelayakan Implementasi E-Government Dalam Pelayanan Publik Di Bidang Keagrariaan Di Kabupaten Pinrang. Jurnal Komunikasi KAREBA, 5(1), 178-91.

Susanto, A. (2015). Faktor-Faktor Yang Memengaruhi Perilaku Penggunaan Internet Masyarakat Desa Pasar VI Kualanamu, Deli Serdang Sumatera Utara. Jurnal Penelitian Pos dan Informatika, 5(1), 65-86. 